\title{
The effect of probiotic nutrition of Saccharomyces boulardii and Saccharomyces cerevisiae on yield, antioxidant activity and expression of interleukin-6 gene in Holstein calves
}

\author{
S. Sabooni, M. Chamani*, A.A. Sadeghi, M. Amin-Afshar and N. E. J. Kashan \\ Department of Animal Science, Science and Research Branch, Islamic Azad University, \\ Tehran - Iran \\ *Corresponding E-mail : m.chamani@srbiau.ac.ir
}

Received August 06, 2020; Accepted October 20, 2020

\begin{abstract}
ABSTRAK
Penelitian dilakukan untuk mengetahui pengaruh probiotik Saccharomyces boulardii dan Saccharomyces cerevisiae terhadap hasil, aktivitas antioksidan, dan ekspresi gen interleukin-6 pada pedet Holstein. Enam belas pedet dibagi menjadi 4 perlakuan ransum dengan 4 pedet/perlakuan. Pakan perlakuan eksperimental meliputi 1) kontrol (tanpa penggunaan probiotik), 2) probiotik yang larut dalam susu berdasarkan $S$. boulardii $(1 \mathrm{~g} / \mathrm{kg}), 3$ ) probiotik yang larut dalam susu berdasarkan $S$. cerevisiae (1 $\mathrm{g} / \mathrm{kg}$ ) dan 4) A campuran probiotik ragi $S$. boulardii dan $S$. cerevisiae sebagai larutan dalam susu sapi (masing-masing $1 \mathrm{~g} / \mathrm{kg}$ ). Rancangan acak lengkap digunakan dalam penelitian ini. Hasil penelitian menunjukkan bahwa pemberian pakan $S$. boulardii dan $S$. cerevisiae tidak berpengaruh nyata dibandingkan dengan kontrol. Tidak ada perbedaan yang signifikan antara perlakuan yang berbeda untuk jumlah enzim antioksidan dibandingkan dengan kontrol. Superoksida dismutase (SOD) pada perlakuan menggunakan probiotik lebih tinggi dibandingkan dengan kontrol. Ekspresi ekspresi gen interleukin-6 meningkat secara signifikan $(\mathrm{P}<0,05)$ untuk perlakuan 3 dan 4 pada hari ke 10, 30 dan 60 dibandingkan dengan kontrol. Kesimpulannya, penambahan probiotik tidak mengubah sifat kinerja aktivitas antioksidan, tetapi perlakuan $S$. cerevisae meningkatkan ekspresi gen interleukin-6 yang menunjukkan efek pada sistem kekebalan.
\end{abstract}

Kata kunci : probiotics, Saccharomyces, Boulard's Saccharomyces, Holstein, calf, performance

\begin{abstract}
An experiment was performed to investigate the probiotic effect of Saccharomyces boulardii and Saccharomyces cerevisiae on yield, antioxidant activity, and expression of interleukin-6 gene in Holstein calves. Sixteen calves were divided into 4 dietary treatments with 4 calves/treatment. Experimental treatment diets include 1) control (without probiotic use), 2) milk soluble probiotics based on $S$. boulardii $(1 \mathrm{~g} / \mathrm{kg})$, 3) milk soluble probiotics based on $S$. cerevisiae $(1 \mathrm{~g} / \mathrm{kg})$ and 4) A mixture of yeast probiotics $S$. boulardii and $S$. cerevisiae as a solution in dairy milk $(1 \mathrm{~g} / \mathrm{kg}$ each). The completely randomized design was used in this experiment. The results showed that feeding S. boulardii and $S$. cerevisiae did not have a significant effect on performance traits compared with control. There was no significant difference between the different treatments for the number of antioxidant enzymes compared to the controls. Superoxide dismutase (SOD) in the treatments used probiotics were higher than the control. The expression of interleukin- 6 gene expression was increased significantly $(\mathrm{P}<0.05)$ for treatments 3 and 4 on Days 10, 30 and 60 compared to the control. In conclusion, addition of probiotics did not alter performance traits of antioxidant activity, but the $S$. cerevisae treatment did increase
\end{abstract}


interleukin-6 gene expression which suggests an effect on the immune system.

Keywords: probiotik, Saccharomyces, Boulard's Saccharomyces, Holstein, calf, performance

\section{INTRODUCTION}

In recent years, the feed composition of infant dairy calves has been considered important for growth and production (Mollenhorst et al., 2016). During the this period, the calves are affected by various types of stresses due to the management system which affects their growth efficiency. Some stresses can reduce the function of growth and the immune system by altering ruminal and intestinal microorganisms, resulting in increased mortality (Seifzadeh et al., 2016). Another harmful effect of these stresses is the production of free radicals. Free radicals are atoms or molecules with single and unsaturated electrons that have a very high chemical reaction (reactivity) to achieve stability, and therefore in the body of living organisms cause damage to various macromolecules such as proteins, lipids, carbohydrates, and nucleic acids and have certain physiological and pathophysiological effects (Halliwell and Gutteridge, 2015).

The most important free radicals are hydrogen peroxide ( $\mathrm{H} 2 \mathrm{O} 2)$, anion superoxide $(\mathrm{O} 2-)$, and radical hydroxyl $(\mathrm{OH})$ (Poorghasemi et al., 2013).

The most destructive effect of these free radicals is on the cell membrane and the membrane of intracellular organs such as the mitochondrial membrane. These reactive oxygen species (ROS) cause peroxidation of lipids which can damage phospholipid membrane of cells and the cell wall to harden, thus affecting many of the cell's activities (Martarelli et al., 2011).

Production of free radicals and ROS in the body's cells is inevitable, but the body also uses a complex and skilled defense system called antioxidants, which includes enzymatic and nonenzymatic reactions (Martarelli et al., 2011).

The most important enzymatic antioxidants are superoxide dismutase (SOD), glutathione peroxidase (GPX), and catalase (CAT). Also, nonenzymatic antioxidants include some vitamins, a number of trace elements, and probiotics (Shwartz et al., 2009).

Some researchers believe that enzymatic antioxidants are not enough to prevent oxidative damage, and oral additives can be effective. In recent decades, probiotics have been shown to be one of the most important dietary supplements, stimulating growth, increasing antioxidant capacity, and boosting the immune system (Moslemipur et al., 2014).

Probiotics are living microorganisms that, if consumed in moderation, can have beneficial effects on host health. These microorganisms are widely used to treat infections, allergies, and inflammatory diseases, and act by balancing the population of intestinal microbial flora. They have been shown to have a positive effect on improving animal performance and function of their immune system (Salarmoini et al., 2019).

As can be seen, immune responses fall into two categories, hemoral (antibody dependent) and cellular ( $\mathrm{T}$ cell dependent). Removal of soluble antigens and destruction of extracellular microorganisms is the main task of hemoral immunity (due to antibodies produced by B cells) and elimination of intracellular microorganisms (due to T cells). Antibodies are a group of proteins in globulin that are involved in immunity and are called immunoglobulins. One of the signals for activating the hemoral immune response is cytokines such as interleukin-6, which activate helper T lymphocytes, proliferate and differentiate B cells. In fact, interleukin-6 is effective on plasma cells and lymphocytes, and the main function of this cytokine is to differentiate plasma cells faster and produce more antibodies (Downing et al., 2010).

Probiotics inhibit oxidative stress by reducing inflammatory lesions and increasing the levels of antioxidant enzymes such as superoxide dismutase and glutathione peroxidase. Probiotics increase the ratio of $\mathrm{T}$ lymphocytes to suppressive T lymphocytes. Probiotics have been shown to increase interleukin-6 levels and boost the host's immune system (Fantuzzi, 2005).

Saccharomyces are the most important industrial yeast for the production of fermented products, recombinant proteins, and monounsaturated proteins. The genus Saccharomyces includes two well-known species, Saccharomyces cerevisiae, and Saccharomyces bullardis. Saccharomyces cerevisiae is the most famous yeast and fermenter of carbohydrates, which can be effective in the immune system by applying various mechanisms (Martins et al., 2007).

Saccharomyces bollard is also one of the 
most widely used probiotics and is commonly used to fight intestinal pathogenic microorganisms and therefore can have special benefits in improving host performance (Rajkowska et al., 2014). In their experiment, Lascano et al. (2009) concluded that the probiotic yeast Saccharomyces bullardi had the potential to improve intestinal health by reducing the duration and severity of diarrhea.

A number of studies have demonstrated the effects of yeast probiotics on improving performance parameters in livestock (Ayad et al., 2013). Wang et al. (2009) concluded in an experiment that adding probiotics at the end of the pig breeding period increased the antioxidant capacity of the animal serum so that the GPX and serum SOD were increased. Hardy et al. (2013) also reported in their experiment that the use of probiotics increases the function and antioxidant activity.

Given the importance and sensitivity of dairy calf production and the positive effect of probiotics as an additive on growth, health, and immune syestem function, the present study aimed to investigate the use of two type of probiotic yeast separately and in combination on performance, antioxidant activity and expression of the interleukin- 6 gene in dairy calve.

\section{MATERIALS AND METHODS}

The present study used 16 newly born Holstein calves with an average birth weight of 2.542 .5 (unclear what is intended) $\mathrm{kg}$ after feeding with colostrum. When 3 days old, the calves were randomly allocated to 4 treatments ( sample size $=4$ calves/treatment). The experimental treatment diets were 1) control (without probiotic use), 2) daily soluble probiotic based on Saccharomyces boulardii $(1 \mathrm{~g} / \mathrm{kg}), 3)$ daily soluble probiotic based on Saccharomyces cerevisiae $(1 \mathrm{~g} / \mathrm{kg})$ and 4) A mixture of Saccharomyces boulardii and Saccharomyces cerevisiae yeast probiotics as a solution in dairy milk ( $1 \mathrm{~g} / \mathrm{kg}$ each).

Saccharomyces cerevisiae CNCM-1077 yeast probiotics and Saccharomyces cerevisiae var. Boulardii CNCM I-1079 (Saccharomyces cerevisiae var. Boulardii CNCM I-1079) were used in this study, respectively $2 \times 10^{10} \mathrm{~g} / \mathrm{CFU}$ was a living yeast cell.

The calves were fed colostrum $(10 \%$ of body weight) from day one to day three. Since the fourth day, 4 liters of milk per day was fed to the calves. In addition to milk, the calves had free access to a fully mixed diet. The calves' diets were adjusted using the NRC table (2011). The nutrients used in the diet and its chemical composition are presented in Table $1.10 \%$ of alfalfa (substituted with wheat bran) in sizes of 2 to $3 \mathrm{~cm}$ at 35 days of age of calves was added to the initial feed.

\section{Performance}

From the fourth day, the calves' food was weighed daily by a digital scale and given to them ad libidum. By deducting the remaining amount of food from the initial amount the next morning, the amount of food eaten by each calf was recorded, and the feed consumed for the whole period was calculated. The calves' weight was measured every ten days before the morning meal. To obtain the average weight gain of the whole period, by dividing the difference in the amount of weight at the end of each calf period, the birth weight was used based on the number of days spent in the relevant period. Finally, the feed conversion ratio for each calf was obtained by dividing the feed consumed throughout the period by the weight gain over the entire period.

To measure antioxidant activity, blood sampling was performed before feeding in the morning on the 10th, 30th, and 60th days at the beginning of each treatment. Blood was drawn from the tail vein and allowed to clot. To prepare the serum, the test tubes containing blood samples were centrifuged at $3000 \mathrm{rpm}$ for 20 minutes. Serum samples were stored at -20 . C to determine antioxidant parameters.

The activity of antioxidant indicators was measured using Pars Azmoun commercial kits by Eliza Reader device (ELX800 model, Bio-Tek) at a wavelength of $412 \mathrm{~nm}$ for glutathione peroxidase activity. The concentration of superoxide dismutase was calculated by nitroblotrazole (NBT) at $560 \mathrm{~nm}$. The activity of the enzyme catalase was also measured by the Claiborne method at $240 \mathrm{~nm}$

\section{Interleukine-6 gene expression (IL)}

Blood samples were collected to be examined for IL-6 gene expression at the end of the treatment period. It was transferred to a liquid nitrogen tank at the Molecular Genetics and Biotechnology Laboratory and stored at $-80 \mathrm{C}$ until RNA extraction. Total RNA was isolated 
Table 1. Nutritional Values and Chemical Compounds of Starter Diet

\begin{tabular}{|c|c|c|c|}
\hline Dietary compounds & Percentage in diet & Chemical compounds & Percentage in diet \\
\hline Barley & 5 & $\mathrm{DM}$ & 88.851 \\
\hline Corn grain & 35 & TDN & 83.476 \\
\hline Soybean meal & 33.2 & $\mathrm{CP}$ & 18.83 \\
\hline Wheat barn & 20 & $\mathrm{CF}$ & 4.338 \\
\hline Ground salt & 1 & $\mathrm{EE}$ & 8.712 \\
\hline Calcium carbonate & 1.2 & NDF & 10.93 \\
\hline Magnesium oxide & 0.3 & $\mathrm{ADF}$ & 5.652 \\
\hline Di-calcium phosphate & 0.3 & $\mathrm{Ca}$ & 1.076 \\
\hline Sodium bicarbonate & 1 & $\mathrm{P}$ & 0.443 \\
\hline Vitamin Supplement $^{1}$ & 1.5 & & \\
\hline Mineral supplement ${ }^{2}$ & 1.5 & & \\
\hline Total & 100 & & \\
\hline
\end{tabular}

DM: dry matter; TDN: total digestible nutrients; CP: crude protein; CF: crude fibre; EE: ether extracts; NDF: neutral detergent fiber and ADF: acid detergent fiber

${ }^{1}$ Vitamin premix (mg/kg diet): vitamin A: $2000000 \mathrm{IU}$; vitamin D: $25000 \mathrm{IU}$; vitamin E: $3000 \mathrm{IU}$ and Antioxidant: $600 \mathrm{mg}$.

${ }^{2}$ Mineral premix (mg/kg diet): Cu: 12500 mg; Co: 10 mg; I: 100 mg; Fe: 400 mg; Mn: 10 mg; Zn: 6500 mg and Se: $10 \mathrm{mg}$.

from blood samples using a one-way test company according to the manufacturer's instructions. To make cDNA from Qiagen's QuantiFast Reverse Transcriptase kit (QIAGEN, 205311), and according to the manufacturer's instructions, the cDNA of each sample was prepared from its extracted RNA. The sequence of primers used to study the IL-6 gene included primers for real-time PCR and primers for the GAPDH gene as the internal control for normalization (Table 2). Using Real-time PCR primers and using Sybergreen, gene expression was evaluated in cDNA samples prepared from the experimental sample (Poorghasemi et al., 2017).

\section{Statistical Analysis}

The data collected in a completely randomized design were statistically analyzed using the General Linear Model (GLM) and statistical software SAS (2004). The averages was compared using Duncan's test at 5\% probability level. The statistical model of the design was $\mathrm{Yij}=$ $\mu+\mathrm{A}+$ eij. In this model, Yij: The value of each observation for the studied attribute, $\mu$ : Average observations, Ai: The effect of experimental treatments and eij: The effect of experimental error.

\section{RESULTS}

Table 3 shows the effect of experimental treatments on performance traits in calves. The difference in weight and mean body weight of calves in experimental treatments did not differ significantly from control $(\mathrm{P}>0.05)$. Also, the mean of dry matter intake and conversion factor of any of the treatments were not significantly different from the control $(\mathrm{P}>0.05)$. Table 4 presents the results of the effect of experimental treatments on the activity of serum blood antioxidant enzymes. Accordingly, the amount of antioxidant enzymes GPX, CAT, and SOD in the blood serum of calves at the ages of 10,30 , and 60 days was not significantly different between the treatments $(\mathrm{P}>0.05)$. Table 5 shows the results of the experimental diets on the expression of the interleukin- 6 gene. On the 
Table 2. The Sequence of Primers Designed to Real Time PCR

\begin{tabular}{lccc}
\hline Gene Symbol & Direction & Sequence of the Primers & Product size $(\mathrm{pb})$ \\
\hline \multirow{2}{*}{ IL-6 } & Forward & 5'-TGATGGATGCTTCCAAACTG-3' & 20 \\
& Reverse & 5'-GAGCATTGGAAGTTGGGGTA-3' & 20 \\
\multirow{2}{*}{ GAPDH } & Forward & 5'-GTATTGGGCGCCTGGTCACC-3' & 20 \\
& Reverse & 5'-CGCTCCTGGAAGATGGTGATGG-3' & 22 \\
\hline
\end{tabular}

Table 3. The Effect of Experimental Treatments on Calf Performance

\begin{tabular}{lcccccc}
\hline \multicolumn{1}{c}{ Performance Traits } & T1 & T2 & T3 & T4 & SEM & P-value \\
\hline Weight (kg) & $52.022^{\mathrm{a}}$ & $54.447^{\mathrm{a}}$ & $56.982^{\mathrm{a}}$ & $58.882^{\mathrm{a}}$ & 2.708 & 0.345 \\
$\begin{array}{l}\text { Feed Consumption } \\
\text { (kg/cow per 60 d) }\end{array}$ & $28.941^{\mathrm{a}}$ & $34.906^{\mathrm{a}}$ & $34.908^{\mathrm{a}}$ & $39.007^{\mathrm{a}}$ & 4.259 & 0.357 \\
$\begin{array}{l}\text { Body weight gain } \\
\text { (kg/cow per 60 d) }\end{array}$ & $20.750^{\mathrm{a}}$ & $25.500^{\mathrm{a}}$ & $26.000^{\mathrm{a}}$ & $29.329^{\mathrm{a}}$ & 3.036 & 0.395 \\
Feed conversion ratio & $1.394^{\mathrm{a}}$ & $1.368^{\mathrm{a}}$ & $1.342^{\mathrm{a}}$ & $1.329^{\mathrm{a}}$ & 0.099 & 0.998 \\
\hline
\end{tabular}

T1: Control; T2: S. boulardii (1 g/kg of diet); T3: S. cerevisiae (1 g/kg of diet) and T4: S. boulardii $(1 \mathrm{~g} / \mathrm{kg}$ of diet) + S. cerevisiae $(1 \mathrm{~g} / \mathrm{kg}$ of diet $)$.

The means within the same row with at least one common letter, do not have significant difference $(\mathrm{P}<0.05)$.

SEM: standard error of the means.

tenth day of the experiment, the expression of interleukin-6 gene expression was significant for treatments 3 and 4 with control $(\mathrm{P}<0.05)$. On days 30 and 60 of the experiment, the difference in expression of the interleukin-6 gene in calves using probiotics increased significantly $(\mathrm{P}<0.05)$.

\section{DISCUSSION}

Also, the average dry matter intake of probiotic-containing treatments increased more than in the control group, and the conversion factor of these treatments improved. Researchers have reported that feeding probiotics improved the daily weight gain of dairy calves, possibly due to improved microbial flora and maximum livestock use of dietary nutrients (Riddell et al., 2010). In newborn calves or under environmental stress, the microbial population can change dramatically. It seems probiotics can accelerate their daily weight gain by accelerating the animal's habituation to solid foods and reducing the number of bacteria that cause infectious diarrhea (Lorenzoni et al., 2012).

According to the results of the present experiment, the treatments did not affect growth characteristics. Neither weight, feed consumption nor feed conversion of the probiotic-treated calves differed significantly from the control treated group.

According to the findings of the present study, the dry matter intake of calves fed probiotics was not affected compared to the control group (Mohamadi Roodposhti and Dabiri, 2012). Although this increase was not significant in the present experiment, its effect on the weight gain of probiotic consuming calves is quite evident. According to the researchers, the increase in dry matter intake in calves depends on the development of ruminal epithelium and its capacity, as well as the rapid adaptation of calves to solid feed (Hossain et al., 2012).

Adding probiotics to the feed consumed 
Table 4. The Effect of Experimental Treatments on the Activity of Serum Calf Antioxidant Enzymes at Different Ages

\begin{tabular}{lcccccc}
\hline \multicolumn{1}{c}{ Antioxidant enzymes } & $\mathrm{T} 1$ & $\mathrm{~T} 2$ & $\mathrm{~T} 3$ & $\mathrm{~T} 4$ & SEM & P-value \\
\hline Glutathione peroxidase (GPX) & & & & & & \\
day 10 & $3.888^{\mathrm{a}}$ & $9.615^{\mathrm{a}}$ & $10.059^{\mathrm{a}}$ & $11.631^{\mathrm{a}}$ & 3.298 & 0.421 \\
Day 30 & $4.425^{\mathrm{a}}$ & $8.802^{\mathrm{a}}$ & $10.394^{\mathrm{a}}$ & $15.11^{\mathrm{a}}$ & 6.430 & 0.433 \\
$\quad$ Day 60 & $6.916^{\mathrm{a}}$ & $8.822^{\mathrm{a}}$ & $12.598^{\mathrm{a}}$ & $21.376^{\mathrm{a}}$ & 5.887 & 0.618 \\
Catalase (CAT) & & & & & & \\
$\quad$ Day 10 & $0.270^{\mathrm{a}}$ & $0.270^{\mathrm{a}}$ & $0.270^{\mathrm{a}}$ & $0.270^{\mathrm{a}}$ & 0.000 & 0.802 \\
Day 30 & $0.270^{\mathrm{a}}$ & $0.270^{\mathrm{a}}$ & $0.270^{\mathrm{a}}$ & $0.270^{\mathrm{a}}$ & 0.000 & 0.916 \\
Day 60 & $0.271^{\mathrm{a}}$ & $0.271^{\mathrm{a}}$ & $0.271^{\mathrm{a}}$ & $0.271^{\mathrm{a}}$ & 0.001 & 0.693 \\
Superoxide dismutase (SOD) & & & & & & \\
$\quad$ Day 10 & $200^{\mathrm{a}}$ & $431.2^{\mathrm{a}}$ & $495.6^{\mathrm{a}}$ & $518^{\mathrm{a}}$ & 97.443 & 0.162 \\
Day 30 & $216^{\mathrm{a}}$ & $416.7^{\mathrm{a}}$ & $522.1^{\mathrm{a}}$ & $631.7^{\mathrm{a}}$ & 207.663 & 0.564 \\
Day 60 & $326.3^{\mathrm{a}}$ & $432.2^{\mathrm{a}}$ & $543.1^{\mathrm{a}}$ & $785.5^{\mathrm{a}}$ & 178.637 & 0.365 \\
\hline
\end{tabular}

T1: Control; T2: S. boulardii (1 g/kg of diet); T3: S. cerevisiae (1 g/kg of diet) and T4: S. boulardii $(1 \mathrm{~g} / \mathrm{kg}$ of diet $)+S$. cerevisiae $(1 \mathrm{~g} / \mathrm{kg}$ of diet $)$.

The means within the same row with at least one common letter, do not have significant difference $(\mathrm{P}<0.05)$.

SEM: standard error of the means.

by calves at the beginning of their birth has affected the function of the rumen so that these calves will be more inclined to eat than the control. This suggests that probiotics may have increased ruminal development. As a result, as the rumen expands, the number of papillae and the level of absorption increase, which increases the dry matter intake (Nakanishi et al., 1993).

In the present experiment, calves fed probiotics had a better conversion factor than control. Using a mixture of $S$. boulardii and $S$. cerevisiae had the best conversion factor, although no significant difference was observed with control and other treatments. It seems that one of the reasons for the improvement in conversion ratio in probiotic treatments has been the improvement in animal health. Given that probiotics can improve the supply of microbial protein by developing rumen and improving the process of ruminal fermentation, they will improve the conversion factor. By stimulating cellulose bacteria and bacteria producing ruminal lactate, probiotics increase digestibility and increase the passage of microbial protein through the rumen and increase the supply of microbial protein in the large intestine, which allows livestock to access more nutrients and improve conversion ratio (Hillman et al., 2017).

The results of this study showed that the use of yeast probiotics did not affect the CAT activity of calves' blood serum compared to the control group. Also, according to the results, the amount of GPX and SOD enzymes in calves that had consumed probiotics, although not significantly different from the control was higher in all three measured times. In an experiment conducted on Swiss Brown infant calves, Tunc and Yoruk (2012) concluded that adding 0.15\% 
Table 5. The Effect of Experimental Treatments on the Expression of Interleukin-6 Gene in Calves at Different Ages

\begin{tabular}{lcccccc}
\hline Interleukine-6 & $\mathrm{T} 1$ & $\mathrm{~T} 2$ & $\mathrm{~T} 3$ & $\mathrm{~T} 4$ & SEM & P-value \\
\hline Day 10 & $1.000^{\mathrm{b}}$ & $0.596^{\mathrm{b}}$ & $1.765^{\mathrm{a}}$ & $1.768^{\mathrm{a}}$ & 0.171 & 0.003 \\
Day 30 & $1.000^{\mathrm{b}}$ & $2.23^{\mathrm{a}}$ & $2.263^{\mathrm{a}}$ & $2.862^{\mathrm{a}}$ & 0.222 & 0.002 \\
Day 60 & $1.000^{\mathrm{c}}$ & $5.964^{\mathrm{b}}$ & $10.781^{\mathrm{a}}$ & $14.381^{\mathrm{a}}$ & 1.160 & 0.000 \\
\hline
\end{tabular}

T1: Control; T2: S. boulardii (1 g/ $/ \mathrm{kg}$ of diet); T3: S. cerevisiae $(1 \mathrm{~g} / \mathrm{kg}$ of diet) and T4: S. boulardii $(1 \mathrm{~g} / \mathrm{kg}$ of diet) + S. cerevisiae $(1 \mathrm{~g} / \mathrm{kg}$ of diet $)$.

The means within the same row with at least one common letter, do not have significant difference $(\mathrm{P}<0.05)$.

SEM: standard error of the means.

probiotics to the basal fluid during the first 12 weeks of infancy had a significant effect on GPX, CAT and SOD had no antioxidant enzymes.

However, various studies have shown that the use of probiotics affects the antioxidant status of the animal so that animals use the ability of probiotics to increase the level of antioxidants and neutralize the effects of various ROS (Truusalu et al., 2004). In fact, probiotics play a stimulating role in the production of antioxidants and the breakdown of free radicals through the production of butyric and hydrogen acids (Martarelli et al., 2011).

Wang et al. (2016) proposed that the use of a diet containing probiotics leads to an increase in the body's antioxidant activity. They said that probiotics, as an antigen, stimulated the secretion of antioxidant enzymes and increased antioxidant secretion, leading to the elimination of free and excess radicals produced by high metabolism and adverse environmental stress. It protects the body's tissues and organs by regulating the balance of free radical.

As can be seen from the results, the amount of antioxidant enzymes was higher in 60 days than in 10 and 30 days, which could be due to the increase in high metabolism and the production of more free radicals to increase growth (Persichetti et al., 2014).

The present results for the expression of interleukin- 6 gene indicate that both boulardii and cerevisiae have been effective on interleukin-6 levels, but at the end of the period, the application of a mixture of both species has been able to increase interleukin- 6 levels more than at other times.

Probiotics cause beneficial bacteria in the gut, which have many immunological and metabolic functions. Beneficial bacteria in the gut affect the function of the immune system by interacting with intestinal epithelial cells and lymphatic tissues around the gastrointestinal tract. In fact, probiotics increase the ability of these bacteria to strengthen the body's immune system and mucosal defenses (Dowarah et al., 2018).

Stimulation of the immune system with probiotics may be due to increased T-type lymphocytes, phagocytes, and serum protein levels, which are associated with the secretion of cytokines by cells of the immune system stimulated by probiotics (Bai et al., 2011).

Interleukin- 6 is secreted by $T$ cells and macrophages to stimulate the immune response (Poorghasemi et al., 2015).

Since interleukin-6 is related to Th2related lymphocytes, it can be concluded that yeast probiotics $S$. cerevisiae, $S$. boulardii increase the number of Th2 lymphocytes (Fooks and Gibson, 2002). The effects of probiotics on the immune system have been reported in several studies (Scharek et al., 2005; Benyacoub et al., 2003).

However, the exact mechanism of action of probiotics on the immune system and their 
differentiating effects on different lymphocytes and cytokines is not yet well understood. One possible mechanism of action is that the cell wall of probiotics has immune-stimulating compounds, such as peptidoglycans, that increase the activity of immune-related cells in the intestinal wall. Antigen-expressing dendritic cells are one of the most important cells in the intestinal wall that respond to the presence of probiotics, and by increasing the expression of cytokines, it ultimately increases the number of T cells in the body (Smits et al., 2005). Studies have also shown that probiotics can delay apoptosis in lymphocytes, thereby increasing the level of lymphocytes in the blood (Scharek et al., 2005).

\section{CONCLUSION}

The results of this experiment showed that the use of probiotics as an additive in the diet of calves, although it improved the growth performance and antioxidant activity of calves, but had no significant effect. It seems that the lack of significant performance is due to the amount and type of probiotics consumed. Probably because probiotics in milk reduce palatability, they affect food intake and make performance insignificant. On the other hand, because the experiment was conducted in the warm season, heat stress factors may affect the efficiency of probiotic use. Also, the use of probiotics in the early days of calves' life significantly increased the relative expression of the interleukin- 6 gene, which will increase the efficiency of the immune system. In general, the present study showed that although the separate application of Saccharomyces species can affect performance, antioxidant activity, and the immune system, the use of a mixture of the two species together can have more favorable effects.

\section{REFERENCES}

Ayad, M.A., B. Benallou, M. S. Saim, M. A. Smadi and T. Meziane. 2013. Impact of feeding yeast culture on milk yield, milk components, and blood components in Algerian dairy herds. J. Veterinar. Sci. Technol. 4 (2):1-5.

Bai, S. P., A. M. Wu, X. M. Ding, Y. Lei, J. Bai, K. Y. Zhang and J. S. Chio. 2011. Effects of probiotic-supplemented diets on growth performance and intestinal immune characteristics of broiler chickens. Poult. Sci. 92:663-670.

Benyacoub, J., G. Czarnecki-Maulden, C. Cavadini, T. Sauthier, R. Anderson, E. Schiffrin and W. T. Von der. 2003. Supplementation of food with Enterococcus faecium (SF68) stimulates immune functions in young dogs. J. Nutr. 133:11581164.

Dowarah, R., A. K. Verma, N. Agarwal, P. Singh and B. R. Singh. 2018. Selection and characterization of probiotic lactic acid bacteria and its impact on growth, nutrient digestibility, health and antioxidant status in weaned piglets. PLoS One. 13 (3): $\mathrm{e} 0192978$.

Downing, T., A. T. Lloyd, C. O'Farrelly and D. G. Bradley. 2010. The differential evolutionary dynamics of avian cytokine and TLR gene classes. J. Immunol. 184:6993-7000.

Fantuzzi, G. 2005. Adipose tissue, adipokines, and inflammation. J. Allergy Clin. Immunol. 115 (5):911-919.

Fooks, L and G. Gibson. 2002. In vitro investigations of the effect of probiotics and prebiotics on selected human intestinal pathogens. FEMS Microbiol. Ecol. 39 (1):67-75.

Halliwell, B and J. M. C. Gutteridge. 2015. Free radicals in biology and medicine. $5^{\text {th }}$ Edition, Oxford University Press, New York.

Hardy, H., J. Harris, E. Lyon, J. Beal and A. D. Foea. 2013. Probiotics, prebiotics and immunomodulation of gut mucosal defences: Homeostasis and immunopathology. Nutr. 5 (6):1869-1912.

Hillman, E. T., H. Lu, T. Yao and C. H. Nakatsu. 2017. Microbial ecology along the dastrointestinal tract. Microbs. Environ. 32 (4):300-313.

Homayouni-Rad, A., J. Mohtadi-Nia, M. Niafar and H. Ejtahed. 2012. Probiotic yogurt improves antioxidant status in type 2 diabetic patients. Nutr. J. 28:539-543.

Hossain, S. A., S. Parnerkar, N. Haque, R. S. Gupta, D. Kumar and A. K. Tyagi. 2012. 
Influence of dietary supplementation of live yeast (Saccharomyces cerevisiae) on nutrient utilization ruminal and biochemical profiles of Kankrej calves. Int. J. Appl. Anim. Res. 1 (1):30-38.

Lascano, G. J., G. I. Zanton, M. F. Suarez-Mena and A. J. Heinrichs. 2009. Effect of limit feeding highand low-concentrate diets with Saccharomyces cerevisiae on digestibility and on dairy heifer growth and firstlactation performance. J. Dairy Sci. 92 (10):5100-5110.

Lorenzoni, A. G., S. Pasteiner, M. Mohnl and F. Perazzo. 2012. Probiotics: Challenging the traditional modes of action. Iranian J. Appl. Anim. Sci. 2 (1):33-37.

Martarelli, D., M. C. Verdenelli, S. Scuri, M. Cocchioni, S. Silvi, C. Cecchini and P. Pompei. 2011. Effect of a probiotic intake on oxidant and antioxidant parameters in plasma of athletes during intense exercise training. Curr. Microbiol. 62:1689-1696.

Martins, F. S., A. C. P. Rodrigues, F. C. P. Tiago, F. J. Penna, C. A. Rosa, R. M. E. Arantes, R. M. D. Nardi, M. J. Neves and J. R. Nicoli. 2007. Saccharomyces cerevisiae strain 905 reduces the translocation of Salmonella enterica serotype Typhimurium and stimulates the immune system in gnotobiotic and conventional mice. J. Med. Microbiol. 56:352-359.

Mohamadi Roodposhti, P and N. Dabiri. 2012. Effects of probiotic and prebioticon average daily gain, fecal shedding of Escherichia coli and immune system status in newborn female calves. Asian-Australas J. Anim. Sci. 25 (9):1255-1261.

Mollenhorst, H., P. B. M. Berentsen, H. Berends, W. J. J. Gerrits and I. J. M. de Boer. 2016. Economic and environmental effects of providing increased amounts of solid feed to veal calves. J. Dairy Sci. 99:2180-2189.

Moslemipur, F., F. Moslemipur, and Y. Mostafaloo. 2014. Effects of using probiotic and synbiotic in colostrum and milk on passive immunoglobulin transfer rate, growth and health parameters of calf. J. Rumin. Res. 4:56-62.

Nakanishi, Y., C. W. Arave and P. H. Stewart. 1993. Effect of feeding Lactobacillus acidophilus yogurt on performance and behavior of dairy calves. J. Dairy Sci. 76 (1):244-251.

NRC. 2001. Nutrient Requirements of Dairy
Cattle. $7^{\text {th }}$ Ed. National Academy Press, Washington, DC, USA.

Persichetti, E., A. De Michele, M. Codini and G.

Traina. 2014. Antioxidative capacity of

Lactobacillus fermentum LF31 evaluated in vitro by oxygen radical absorbance capacity assay. Nutr. 30:936-938.

Poorghasemi, M., M. Chamani, S. Z. Mirhosseini, A. A. Sadeghi and A. Seidavi. 2017. Effect of probiotic and different sources of fat on performance, carcass characteristics, intestinal morphology and ghrelin gene expression on broiler chickens. Kafkas Univ. Vet. Fak. Derg. 24 (2):169-178.

Poorghasemi, M., A. R. Seidavi and A. A. A. Qotbi. 2013. Investigation on fat source effects on broiler chickens performance. Res. J. Biotechnol. 8 (1):78-82.

Poorghasemi, M., A. R. Seidavi, A. A. A. Qotbi, J. R. Chambers, V. Laudadio and V. Tufarelli. 2015. Effect of dietary fat source on humoral immunity response of broiler chickens. Eur. Poult. Sci. 79:1-8.

Rajkowska, K., A. Kunicka-Styczynska and A. Rygala. 2014. Probiotic activity of Saccharomyces cerevisiae var. boulardii against human pathogens. Food Technol. Biotechnol. 50 (2):230-236.

Riddell, J. B., A. J. Gallegos, D. L. Harmon and K. R. Mcleod. 2010. Addition of a Bacillus based probiotic to the diet of pre ruminant calves: Influence on growth, health, and blood parameters. Int. J. Appl. Res. Vet. Med. 8 (1):78-85.

Salarmoini, M., A. Salajegheh, M. H. Salajegheh and M. Afsharmanesh. 2019. The effect of lavender (Lavandula angustifolia) extract in comparison to antibiotic on growth performance, intestinal morphology, ileal microflora, antioxidant status and meat quality of broilers. Iranian J. Appl. Anim. Sci. 9 (4):717-725.

SAS Institute. 2004. SAS ${ }^{\circledR} /$ STAT Software, Release 9.4. SAS Institute, Inc., Cary, NC. USA.

Scharek, L., J. Guth, K. Reiter, K. Weyrauch and D. Taras. 2005. Influence of a probiotic Enterococcus faecium strain on development of the immune system of sows and piglets. Vet Immun. Immunopathol. 105 (1):151-161.

Seifzadeh, S., F. Mirzaei Aghjehgheshlagh, H. Abdibenemar, J. Seifdavati and B. 
Navidshad. 2016. The effects of a medical plant mix and probiotic on performance and health status of suckling Holstein calves. Italian J. Anim. Sci. 16 (1):44-51.

Shwartz, G., M. L. Rhoads, M. J. VanBaale, R. P. Rhoads and L. H. Baumgard. 2009. Effects of a supplemental yeast culture on heatstressed lactating Holstein cows. J. Dairy Sci. 92:935-942.

Smits, H., A. Engering, D. Van der Kleij, E. de Jong, K. Schipper, T. van Capel, B. A. J. Zaat, M. Yazdanbakhsh, E. A. Wierenga, Y. van Kooyk and M. L. Kapsenberg. 2005. Selective probiotic bacteria induce IL-10producing regulatory $\mathrm{T}$ cells in vitro by modulating dendritic cell function through dendritic cell-specific intercellular adhesion molecule 3-grabbing nonintegrin. Allergy J. Clin. Immunol. 115 (6):1260-1267.

Truusalu, K., P. Naaber, T. Kullisaar, H. Tamm, R. H. Mikelsaar, K. Zilmer, A. Rehema, M. Zilmer and M. Mikelsaar. 2004. The influence of antibacterial and antioxidative probiotic Lactobacilli on gut mucosa in a mouse model of Salmonella infection. Microb. Ecol. Health Dise. 16:180-187.

Tunc, M. A and M. A. Yoruk. 2012. The effect of humic acid on rumen parameters, protozoa count and blood parameters in sheep. Kafkas Univ. Vet. Fak. Derg. 18:55-60.

Wang, A. N., X. W. Yi, H. F. Yu, B. Dong and S. Y. Qiao. 2009. Free radical scavenging activity of lactobacillus fermentum in vitro and its antioxidative effect on growingfinishing pigs. J. Appl. Microbiol. 107:11401148.

Wang, Y., Y. Wu, Y. Wang, A. Fu, L. Gong, W. Li and Y. Li. 2016. Bacillus amyloliquefaciens SC06 alleviates the oxidative stress of IPEC-1 via modulating Nrf2/Keap1 signaling pathway and decreasing ROS production. Appl. Microbiol. Biotechnol. 101:1-12. 